\title{
CONVERGENCE IN CORPORATE GOVERNANCE: THE CASE OF CHINA AND INDIA
}

\author{
ARJYA MAJUMDAR,
}

O.P. Jindal Global University (New Delhi, India)

https://doi.org/10.21684/2412-2343-2020-7-1- 59-90

China and India face similar challenges in maintaining their aggressive rates of economic growth. While both countries attained economic independence in the late 1940s, each followed a different path in terms of growth. China preferred to open up its economy to foreign direct investment much earlier and only in recent times has it turned towards domestic capital. India, on the other hand, began by attempting to develop local talent and shifted its focus to foreign participation in 1991. This paper examines the politicoeconomic background and the resultant corporate governance paths undertaken by each of these countries. These paths, while diverse, lead to a convergence. In particular, given the nature of concentrated shareholdings in Chinese and Indian companies, by the State in China and by family promoters in India, the second agency problem and the requisite protection of minority shareholders assume considerable importance in both jurisdictions. However, given the nature of corporate governance norms having been transplanted from advanced economies to emerging economies, this convergence may not be suitable or even desirable. This paper posits that emerging economies such as China and India ought to develop and implement corporate governance norms that are separate from those of advanced economies to combat the unique issues arising out of shareholding patterns at home.

Keywords: corporate governance; company law; China; India.

Recommended citation: Arjya Majumdar, Convergence in Corporate Governance: The Case of China and India, 7(1) BRICS Law Journal 59-90 (2020). 
Table of Contents

Introduction

1. Political and Economic Background

1.1. China

1.2. India

2. An Analysis of Existing Corporate Governance Norms

2.1. China

2.2. India

3. Convergence in the Positions of India and China

4. The Case for Divergence

Conclusion

Introduction

India and China face similar challenges in maintaining their aggressive rates of economic growth. While both states as we know them today came into being at mid- $20^{\text {th }}$ century, each has followed a different path in terms of its economic and fiscal policy. China continues to follow a mostly state-centric approach to economic development which at the same time allows the infusion of foreign direct investment (FDI) in the country's financial system. India, conversely, allows private participation in the economy, but was until recently reluctant to open up its doors to foreign participation. 'While China outpaces India in terms of growth rate, there are comparatively few indigenous Chinese firms that are internationally competitive. Indian firms, on the other hand, are internationally competitive and enjoy a global presence thanks to the focus in India on the development of local talent.

One of the key indicators of sustain able economic growth is that of good corporate governance and its implementation. In terms of backgrounds, both countries have considerable dissimilarities in their approach towards corporate governance.

India follows a system of family capitalism - one of the most common structures of corporate governance ${ }^{2}$ - demonstrated by concentrated shareholdings in large corporations by wealthy families. Respected business families can leverage their reputations by controlling many listed companies, and subsequently by having listed companies they hold control blocks of other listed companies, in successive

Srabani Roy Choudhury, Japan's Foreign Direct Investment Experiences in India: Lessons Learnt from Firm Level Surveys, Indian Council for Research on International Economic Relations, Working Paper No. 243 (December 2009) (Jan. 4, 2020), available at https://icrier.org/pdf/WorkingPaper243.pdf; see also Tirupati N. Srinivasan, Integrating India with the World Economy: Progress, Problems and Prospects (2001) (Jan. 4, 2020), available at https://pdfs.semanticscholar.org/d3de/e9612d059f3f611d4556b0283a6ebf965305.pdf.

2 Rafael La Porta et al., Corporate Ownership Around the World, 54(2) Journal of Finance 471 (1999). 
tiers of intercorporate ownership. Such pyramidal business groups are common in countries where investors' legal rights are weak. ${ }^{3}$

On the other hand, China follows a form of state capitalism, wherein public officials supervise corporate managers and intervene to correct any governance problems. ${ }^{4}$ If the bureaucratic overseers are able and altruistic, they can direct corporate decision-making down paths that promote the general good. On the other hand, intractable governance problems arise if the public officials have inadequate ability or knowledge to make such decisions, or skew decisions to benefit politically favored persons or groups.

Corporate governance is critically important to a country's economic growth and stability because it provides the credibility and confidence that is fundamental to capital markets. ${ }^{5}$ There are two main categories of shareholders: $(a)$ the promoter and the promoter group and (b) the public shareholding (financial institutions, companies and individuals). For investors to trust a company enough to buy its securities, they need reassurance that the company will be run efficiently and in a transparent manner. This is where corporate governance becomes critical. ${ }^{6}$

Despite the differences between the corporate governance mechanisms followed in India and China, there seems to be a common ground in terms of establishing corporate governance norms in both countries - that of concentrated shareholding wherein the majority of the shares are held by one individual or a group of individuals. This convergence is attributable in no small measure to the influence of the Sarbanes-Oxley Act of 2002 passed in the United States of America and the Cadbury Committee Report in the United Kingdom. ${ }^{8}$

This paper is divided into three parts. The first part examines the political and economic background and the resultant corporate governance paths undertaken by India and China and posits that these paths, while diverse, necessarily lead to a convergence. The second part describes the efforts made by the Chinese and Indian legislatures to mitigate agency problems in firms and argues that the second agency

3 Randall K. Morck \& Lloyd Steier, The Global History of Corporate Governance: An Introduction, National Bureau of Economic Research, Working Paper No. 11062 (November 2005).

4 William Goetzmann \& Elisabeth Köll, The History of Corporate Ownership in China: State Patronage, Company Legislation, and the Issue of Control in A History of Corporate Governance Around the World: Family Business Groups to Professional Managers 149 (R.K. Morck (ed.), Chicago: University of Chicago Press, 2005).

5 Yong Kang et al., Chinese Corporate Governance: History and Institutional Framework (Santa Monica, CA: RAND Corporation, 2008).

6 A History of Corporate Governance Around the World, supra note 4, at 5.

7 Tarun Khanna \& Krishna G. Palepu, The Evolution of Concentrated Ownership in India: Broad Patterns and a History of the Indian Software Industry in A History of Corporate Governance Around the World, supra note 4 , at 83 .

8 Adrian Cadbury, The Financial Aspects of Corporate Governance (London: The Committee on the Financial Aspects of Corporate Governance and Gee and Co. Ltd., 1992). 
problem and the requisite protection of minority shareholders assume considerable importance in both jurisdictions. However, given that the Cadbury Committee Report and the Sarbanes-Oxley Act, both of which emanated from jurisdictions which have typically dispersed shareholding patterns, the question arises as to their efficacy in jurisdictions which exhibit a proclivity towards concentrated shareholding patterns, such as is the case in China and India. In the third and final part, the paper argues that, given the nature of shareholding in China and India, the transplantation of AngloAmerican corporate governance norms to these countries may not be ideal policy.

\section{Political And Economic Background}

\subsection{China}

The strength of Western business organizations was obvious in the first half of the nineteenth century with joint-stock companies like the British East India Company (the most powerful early example) as well as Jardine, Matheson \& Co. in the form of other chartered companies. British registered joint-stock companies engaged in the business of shipping with limited liability has been operational in Shanghai since 1875. China's "first modern corporation," the China Merchants' Steam Navigation Company, was an official attempt to move "beyond lineage trusts and partnerships" to public management (gongsi). Shanghai had a stock exchange by the 1880 s.

In January 1904, the newly created Ministry of Commerce (Shangbu) issued China's first-ever Company Law (Gongsilu)..$^{10}$ The 1904 Company Law was the first modern law drafted by the Imperial Law Codification Commission, whose work was part of the Qing government's new reformist policies in the wake of China's humiliation recently suffered at the hands of Japan and the Western powers. ${ }^{11}$ In giving highest priority to enacting a law governing the organization of commercial companies, the Qing government had several interlocking objectives. It was also believed to be an important tool for the promotion of industrial development in China. ${ }^{12}$ The Chinese felt that only by changing their economic and legal foundations of business relationships could their entrepreneurs compete with their Western and Japanese counterparts.

The idea behind the 1904 Company Law was to overcome the limitations of the partnership form of organization. Perhaps its focus was also to do away with fraudulent

9 William C. Kirby, China Unincorporated: Company Law and Business Enterprise in Twentieth-Century China, 54(1) Journal of Asian Studies 46 (1995).

10 Xusheng Yang, Securities Regulation in China: A Study of its Path to Market Economy (August 1997) (unpublished LL.M. thesis, University of British Columbia) (on file with the UBC Library, University of British Columbia).

11 Kirby 1995.

12 John H. Farrar, Developing Corporate Governance in Greater China, 25(2) University of New South Wales Law Journal 462 (2002). 
activity in guarantorship, which had resulted in the banking crisis at the end of the previous century. ${ }^{13}$

The result was a hybrid of Japanese and English company laws in an abridged form that became the Gongsilu of 1904. This Company Law consisted of as many as 131 articles, and there were four types of company (gongsi) created under it. Three of them, i.e. (a) the partnership (hezi gongsi), (b) the limited partnership (hezi youxian gongsi) which is the equivalent of the dormant partnership and (c) the simple jointstock company (gufen gongsi) of limited and unlimited liability shareholders, which already existed could now be treated as legal entities and given formal organization rules. The novel creation of the law was the company limited by shares (gufen youxian gongsi), wherein the liability of the shareholders was restricted to the value of their respective shares. For the status of a judicial entity with limited liability, it was mandatory to register with the Ministry of Commerce in Peking. The registration fee was assessed as a percentage of the capitalization. ${ }^{14}$

In 1949, the People's Republic of China was founded after the Communist Party took over China. Shortly afterwards all economic sectors were controlled and managed by the government. A very large number of formerly privately owned companies were turned into state-owned companies. Business persons did not have to form entities to carry on their business operations anymore. The state-owned entities had complete financial dependence on the State and did not have to bear their losses or profits independently. ${ }^{15}$ The process was followed throughout the 1950s. Most state-owned companies were not profitable entities on their own and the State was occasionally required to support them financially.

The Chinese government has since then been the majority shareholder of a high proportion of publically listed companies - a main characteristic of Chinese public law companies (PLCs). ${ }^{16}$ Such state-owned enterprises account for approximately 70 percent of the total number of registered firms in China. ${ }^{17}$ The overall impact of state shareholding on corporate value in Chinese PLCs seems to be negative. This appears to be consistent with a number of arguments highlighting the inefficiency of state ownership. ${ }^{18}$ To maximize its political and financial interests the government

13 Kirby 1995.

14 Id.

15 Kingsley T.W. Ong \& Colin R. Baxter, A Comparative Study of the Fundamental Elements of Chinese and English Company Law, 48(1) International \& Comparative Law Quarterly 88 (1999).

16 Andrew Szamosszegi \& Cole Kyle, An Analysis of State-Owned Enterprises and State Capitalism in China, Capital Trade, U.S.-China Economic and Security Review Commission, 26 October 2011 (Jan. 4, 2020), available at https://www.uscc.gov/sites/default/files/Research/10_26_11_CapitalTradeSOEStudy.pdf.

17 Jiwei Wang, A Comparison of Shareholder Identity and Governance Mechanisms in the Monitoring of CEOs of Listed Companies in China, 21(1) China Economic Review 24 (2010).

18 Lihui Tian, Government Shareholding and Value of China's Modern Firms, William Davidson Institute, Working Paper No. 395 (April 2001) (Jan. 4, 2020), available at http://wdi.umich.edu/files/publications/ workingpapers/wp395.pdf. 
shareholder provides both the influencing as well as the facilitating factors to such firms. ${ }^{19}$

The Chinese stock market is composed of the Shanghai Securities Exchange (SHSE) and the Shenzhen Stock Exchange (SZSE), which started operations in December 1990 and July 1991, respectively. ${ }^{20}$ The regulatory authority is the China Securities Regulation Commission (CSRC), founded in October 1992. The CSRC stipulates disclosure rules and governance regulations. The Chinese stock market has grown rapidly since the inception of the CSRC. Between 1992 and 1998, the market capitalization increased at the average rate of 84.7 percent per year. At the end of 1998 , the total market capitalization was about a quarter of China's Gross Domestic Product (GDP). The number of listed companies grew 62 percent annually, from 53 PLCs in 1992 to 851 PLCs in 1998. ${ }^{21}$

In 1993, another Company Law was enacted. It came into force in 1994 establishing the basic features of corporate governance and marking the third stage of the development of corporate governance in China. The 1994 Company Law was the first attempt to create limited companies without regard to the nature of ownership as a part of a modern economic system..$^{22}$ The primary purposes of this Company Law were to restructure the organization and management of state-owned enterprises, address the serious problems of inefficiency, promote competition and productivity and remove the State from management of business operations. However, it provided for control by the State with majority ownership of the largest enterprises. Therefore, privatization was not a part of the agenda of the 1994 Company Law. ${ }^{23}$ While another function was to countenance and promote the development of small private companies, ${ }_{1}^{24}$ the 1994 Company Law envisioned the private sector not as a substitute for state industry but rather as a necessary supplement that would be particularly useful in ameliorating the current problems of unemployment and inefficiency in the economy. ${ }^{25}$

19 Qian Sun et al., How Does Government Ownership Affect Firm Performance? Evidence from China's Privatization Experience, 29(1-2) Journal of Business Finance \& Accounting 1 (2002).

20 H.R. Seddighi \&W. Nian, The Chinese Stock Exchange Market: Operations and Efficiency, 14(11) Applied Financial Economics 785 (2004).

21 Kirby 1995.

22 James V. Feinerman, New Hope for Corporate Governance in China?, The China Quarterly 590 (2007).

23 Ong \& Baxter 1999.

24 See Company Law of the People's Republic of China, adopted by the $5^{\text {th }}$ Meeting of the Standing Committee of the Eighth National People's Congress of the People's Republic of China on 29 December 1993, effective on 1 July 1994, Arts. 51 \& 52. See also Nicholas C. Howson, China's Company Law: One Step Forward, Two Steps Back? A Modest Complaint, 11(1) Columbia Journal of Asian Law 127, 154 (1997).

25 Cindy A. Schipani \& Junhai Liu, Corporate Governance in China: Then and Now, Columbia Business Law Review 1 (2002). 
With the lack of outright stimulation for the private sector in the 1994 Company Law, it comes as no surprise that there are no individuals or household families owning more than 10 percent of the shares in a Chinese PLC. ${ }^{26}$

There has been a shift away from the traditional Marxist ideology to an early English concessionary approach in establishing the concept of a company in China. England, being a primarily capitalist society, has in many respects moved from a more restrictive concession theory approach to a more liberal contractarian form of capitalism. The concessionary approach asserts that companies within the State are legal fictions and their existence is solely accorded to them by the law of the State. Therefore, state-imposed restrictions on incorporation are justified. China, on the other hand, is a socialist state. Therefore, it is suprising to see China adopt the historical English ideological development towards a more contractarian approach. ${ }^{27}$ As a result, China and England both have similar company structures.

\subsection{India}

The Joint Stock Companies Act of 1866 was the primary piece of corporate legislation in India. The subsequent amendments and replacement legislation broadly mirrored the developments in the United Kingdom. In the years immediately following Indian independence, a comprehensive overhaul of company law was undertaken. This resulted in the enactment of the Companies Act 1956. The most recent corporate legislation is the Companies Act 2013 that replaced the 1956 Act. $^{28}$

Formal institutions of corporate governance in India have been in place for many years, though corporate governance issues came to the forefront only following the adoption of the structural adjustment and globalization program by the government in July $1991 .^{29}$ The legal framework for regulating all corporate activities including governance and administration of companies has been in place since the enactment of the Companies Act 1956. ${ }^{30}$ However, since then there has been a sustained effort on the part of the Indian regulators to strengthen corporate governance norms and to promote more stringent governance practices among Indian listed companies. These initiatives have been strongly influenced by developments that occurred in other parts of the world. Clause 49 of the Equity Listing Agreement encapsulates

26 Tian, supra note 18.

27 Ong \& Baxter 1999.

28 N. Balasubramaniam, Strengthening Corporate Governance in India: A Review of Legislative and Regulatory Initiatives in 2013-14, Indian Institute of Management Bangalore, Working Paper No. 447 (June 2014) (Jan. 4, 2020), available at https://www.iimb.ac.in/sites/default/files/2018-07/WP_No._ 447_\%28Revised\%29_0.pdf.

29 Jayati Sarkar \& Subrata Sarkar, Large Shareholder Activism in Corporate Governance in Developing Countries: Evidence from India, 1(3) International Review of Finance 161 (2000).

30 Organisation for Economic Co-operation \& Development, Corporate Governance in Asia: A Comparative Perspective 249 (Paris: OECD Publishing, 2001). 
India's corporate governance norms, and that can be said to owe its genesis to the Cadbury Committee Report in the UK from which it drew broad principles. ${ }^{31}$ Subsequent revisions to Clause 49 can be primarily regarded as a reaction to the Sarbanes-Oxley Act of 2002 in the USA.

In India, companies have a concentrated shareholding pattern where the majority shares are held by a few people belonging to the same family ${ }^{32}$ and who are also the promoters of the company. ${ }^{33}$ Multiple layers of investment in subsidiary companies through stock pyramids $s^{34}$ or cross-holding ${ }^{35}$ is not uncommon in India ${ }^{36}$ and it is difficult to inquire into such forms of holding structures. The concentration of shareholding allows majority shareholders to elect and appoint most of the directors to the company. However, in terms of appointment of directors, the 2013 Act enables small shareholders ${ }^{37}$ to elect "one" director to the board of a listed company. ${ }^{38}$ In spite of this provision for the 'small shareholders director', the cause of the small shareholders in terms of board representation is not furthered. All the decisions of the board require a simple majority (50 percent plus one or more) or a special majority (75 percent or more).

Having majority shareholding, the promoters and promoter group not only influence the board decisions, but they also are in a position to take decisions at shareholder meetings that are beneficial to them without assessing the impact on other minority shareholders. ${ }^{39}$ In the absence of special contractual rights, minority

31 Umakanth Varottil, A Cautionary Tale of the Transplant Effect on Indian Corporate Governance, 21(1) National Law School of India Review 1 (2009).

32 Sarkar \& Sarkar 2000.

33 K.S. Chalapati Rao \& Atulan Guha, Ownership Pattern of the Indian Corporate Sector: Implications for Corporate Governance, Institute for Studies in Industrial Development, Working Paper No. 2006/09 (September 2006) (Jan. 4, 2020), available at http://isid.org.in/pdf/wp0609.PDF. See also Marianne Bertrand et al., Ferreting out Tunneling: An Application to Indian Business Groups, 117(1) Quarterly Journal of Economics 121 (2002).

34 A pyramid structure is where a controlling-minority shareholder holds a controlling stake in a holding company that, in turn, holds a controlling stake in an operating company. See Lucian A. Bebchuk et al., Stock Pyramids, Cross-Ownership and Dual Class Equity: The Mechanisms and Agency Costs of Separating Control from Cash-Flow Rights in Concentrated Corporate Ownership 448 (R.K. Morck (ed.), Chicago: University of Chicago Press, 2000).

35 Companies in a cross-ownership structure are linked by horizontal cross-holdings of shares that reinforce and entrench the power of central controllers. Id. at 450 .

36 Seddighi \& Nian 2004.

37 Companies Act 2013, No. 18, Acts of Parliament, 2013 (India), sec. 151. Explanation defines "small shareholders" as shareholders holding shares of nominal value of not more than 20,000 rupees or such other sum as may be prescribed.

38 Id.

39 Understanding Shareholding Pattern, The Financial Express, 20 February 2013 (In February 2013, even though a significant number of minority shareholders of ACC and Ambuja Cement voted against the 
shareholders are unable to outvote or even veto decisions taken by the majority shareholders.$^{40}$ This concentration of ownership and power leads to greater benefits for the controlling shareholders at the expense of the minority shareholders. Such practices can also have an adverse effect on the development of capital markets, as the minority shareholders are considerably exposed to the actions of the controlling shareholders.

Another effect of the concentrated family ownership structure is that management has little or no stake in the company and constitutes less than 5 percent of large, listed companies. It is not uncommon to see majority shareholders and their family members holding positions on the board. ${ }^{41}$ In a company managed by owners, there is a very strong motivation for management to work for a long-term share price increase. ${ }^{42}$ In a majority of firms there is no separation of chief executive officers and chair, and, therefore, family supremacy is more than covert. This is because the controlling shareholders are in a position to shape the composition of the board of directors. The controlling shareholders are solely responsible for the appointment, renewal and continuance in office of the directors. As a result, all of the directors owe their allegiance to the controlling shareholders. The managers appointed by the board of directors are also indirectly subject to the wishes of the controlling shareholders because they control the board of directors. These characterstics are evident in Indian listed companies, in which significant power rests with the controlling shareholders. ${ }^{43}$

A number of listed companies are also majority owned by multinational companies. Diffused ownership exists only in a handful of Indian listed companies as a matter of exception as opposed to the rule. Examining the ownership aspect empirically, even as late as 2002 the average shareholding of promoters in all Indian companies was as high as 48.1 percent. ${ }^{44} \mathrm{~A}$ more recent study conducted, using data as of June 2015, as issued by the National Stock Exchange, confirms

resolution which was seeking a hike in the royalty payment made to their parent company, Holcim, the resolution was nevertheless passed because the promoters held 50.3 percent and 50.6 percent in ACC and Ambuja Cement, respectively) (Jan. 4, 2020), available at http://archive.financialexpress. com/news/minority-shareholders-oppose-acc-royalty-hike/1076792.

40 Umakanth Varottil, Evolution and Effectiveness of Independent Directors in Indian Corporate Governance, 6(2) Hastings Business Law Journal 281 (2010).

41 Naazneen Karmali, 22 Year-Old Twins of India's Richest Man Mukesh Ambani Get Board Seats, Forbes, 13 October 2014 (Jan. 4, 2020), available at http://www.forbes.com/sites/naazneenkarmali/2014/10/13/ mukesh-ambanis-22-year-old-twins-get-board-seats/.

42 Manoj Pant \& Manoranjan Pattanayak, Insider Ownership and Firm Value: Evidence from Indian Corporate Sector, 42(16) Economic \& Political Weekly 1459 (2007).

43 Vrajlal K. Sapovadia \& Kandarp Patel, Is Blood Thicker Than Water? Appraising Adequacy of Indian Corporate Governance for Family Based Companies: A Case Study of Satyam Computers (Jan. 4, 2020), available at http://ssrn.com/abstract=1347868.

44 Varottil 2009. 
that the shareholding of Indian promoters and promoter groups is on average 55.53 percent. $^{45}$

There have been several developments with respect to corporate governance in India and the first among them came through the Report of the Kumar Mangalam Birla Committee on Corporate Governance. The Securities Exchange Board of India (SEBI) appointed the Committee on Corporate Governance on 7 May 1999 under the Chairmanship of Shri Kumar Mangalam Birla, a member of the SEBI Board, to promote and raise the standards of corporate governance. ${ }^{46}$ Given the prevailing conditions in the governance of Indian companies and the ensuing state of capital markets, the report was the first formal and comprehensive attempt to develop a Code of Corporate Governance. The sugestions put forth in the report included making amendments in the listing agreement executed by the stock exchanges with the companies apart from measures to improve the standards of corporate governance in listed companies in areas of continuous disclosure of material information (including financial and non-financial) and the manner and frequency of such disclosures. The suggestions also focused on defining the responsibilities of independent and outside directors and the safeguards to be adopted to prevent misuse of insider information and incidents of insider trading.

Subsequently, the Narayana Murthy Report ${ }^{47}$ also of the SEBI Committee on Corporate Governance, was released. This particular committee was constituted because it was the belief of the SEBI that efforts to improve corporate governance standards in India had to continue. The development of standards should complement market dynamics. ${ }^{48}$ The primary issues discussed related to audit committees, audit reports, independent directors, related parties, risk management, directorships and director compensation, codes of conduct and financial disclosures. A few parameters including relative importance, fairness, accountability, transparency, ease of implementation, verifiability and enforceability were used to select the recommendations in the final report.

The adoption of Clause 49 of the Equity Listing Agreement on 23 August 2003 was a seminal event in Indian corporate governance. Clause 49 established a number of

45 Madhura Karnik, Bull Run Opens Doors for Promoters to Raise Capital, Livemint, 8 December 2014 (Jan. 4, 2020), available at http://www.livemint.com/Money/Xg1 JjGlwJUbHaaDAuZ5nkN/Bull-run-opensdoors-for-promoters-to-raise-capital.html (stating that private promoters and the government own 51.5 percent of the total market cap of BSE-listed firms).

${ }^{46}$ Shri Kumar Mangalam Birla et al., Report of the Committee Appointed by the SEBI on Corporate Governance, Securities and Exchange Board of India, 7 May 1999 (Jan. 4, 2020), available at http://www. sebi.gov.in/commreport/corpgov.html.

47 This committee was set up under the chairmanship of N.R. Narayana Murthy.

48 N.R. Narayana Murthy et al., Report of the SEBI Committee on Corporate Governance, Securities and Exchange Board of India, 3 February 2003 (Jan. 4, 2020), available at http://www.nfcg.in/UserFiles/ narayanamurthy2003.pdf. 
governance requirements for listed companies with a focus on the role and structure of corporate boards, internal controls and disclosure to shareholders. ${ }^{49}$ The reforms introduced by Clause 49 closely aligned with international best practice at the time and set higher governance standards for listed companies than most other jurisdictions in Asia. The hallmark of Clause 49 was the introduction of independent directors in the Indian corporate governance system. Clause 49 includes a requirement that all listed companies have independent directors and sets forth some specific duties and obligations for independent directors. These reforms were phased in over several years and now apply to thousands of Indian listed companies. This was further modified ${ }^{50}$ on 17 April 2014 after the new Companies Act 2013 was passed on 30 August 2013. The act provides for a major overhaul in the corporate governance norms for all companies.

The 1994 Company Law in China did little more than to restructure the organization and management of businesses, most of which remained under the control of the State. Private businesses remained as a useful supplement rather than a substitute for state-owned companies. On the other hand, India's concentrated ownership structure for the large majority of its companies remains in its families, rather than in the State.

\section{An Analysis of Existing Corporate Governance Norms}

\subsection{China}

The current system of corporate governance applicable to all listed companies in China dates from 2002. It follows a code-based approach, but one where the requirements are formally adopted when the company develops or revises its rules of corporate governance in the articles of association. The listed companies are required to follow not only the letter of the code but also the spirit while improving corporate governance. ${ }^{51}$ The economic impact of legal procedures became apparent in the case of Chengdu Hongguang Industrial Co., Ltd, ${ }^{52}$ where investors sued over

49 Afra Afsharipour, Directors as Trustees of the Nation? India's Corporate Governance and Corporate Social Responsibility Reform Efforts, 34(4) Seattle University Law Review 995 (2011).

50 Securities and Exchange Board of India, Circular on Corporate Governance in Listed Entities - Amendments to Clauses 35B and 49 of the Equity Listing Agreement, Circular No. CIR/CFD/POLICY CELL/2/2014 (Jan. 4, 2020), available at https://www.sebi.gov.in/legal/circulars/apr-2014/corporate-governance-inlisted-entities-amendments-to-clauses-35b-and-49-of-the-equity-listing-agreement_26674.html.

51 Sean Liu, Corporate Governance and Development: The Case of China, 26(7) Managerial and Decision Economics 445 (2005).

52 Naomi Li, Civil Litigation Against China's Listed Firms: Much Ado About Nothing?, Royal Institute of International Affairs, Asia Programme Working Paper No. 13 (February 2004) (Jan. 4, 2020), available at https://www.chathamhouse.org/sites/default/files/public/General/wpfeb04.pdf. This was the first civil compensation attempt on account of false statements which occurred on 4 December 1998 when a case regarding the directors of Hongguang Industries was filed at Shangai Pudong Xinqu 
falsified listing details. The Shanghai court dismissed the case stating that the claimants had not established that losses were caused by fraudulent statements of the defendants..$^{53}$ The matter was referred to the CSRC. Even though securities law provides that advisors, such as issuers and underwriters, are liable to pay compensation for losses resulting from falsified accounts, there are no indicated methods of instigating such suits. Investors find it hard to take legal action, nor can they receive help from public agencies. The outcome of the Hongguang case led to considerable legal and business debate..$^{54}$

The 2005 Company Law has considerably strengthened the position of the minority shareholders. Companies are now allowed to use cumulative voting, ${ }_{15}^{55}$ if desired, thereby empowering minority shareholders to appoint directors and/or supervisors. ${ }^{56} \mathrm{~A}$ stricter duty of care has been imposed on directors, supervisors and senior management. ${ }^{57}$ Shareholders have the right to bring a derivative suit or direct suit against directors, supervisors and senior management. ${ }^{58}$ The concept of 'piercing the corporate veil' has been introduced, enabling courts to look beyond the principle of limited liability. ${ }^{59}$ Shareholders also have the right to check and make copies of the company's books of accounts ${ }^{60}$ and meeting minutes, allowing share buybacks and granting shareholders the right to petition for liquidation of a company. ${ }^{6}$

Other issues for corporate governance relate to the directors and officers of Chinese listed companies. For example, most directors are inside or executive directors; few companies have many independent directors, leading to insider control. Although Chinese securities regulators attempted to overhaul insider-controlled boards by requiring every listed company to have independent directors forming

People's Court by an investor following a fine and administrative sanction given to the company by the CSRC (Jan. 4, 2020), available at http://www.chathamhouse.org/sites/files/chathamhouse/public/ General/wpfeb04.pdf.

53 Id. The investor claimed that she had suffered losses by investing in Hongguans's shares on the basis of their false statements.

54 Tong Lu et al., How Good Is Corporate Governance in China?, 17(1) China \& World Economy 83 (2007).

55 The term "cumulative voting" as mentioned refers to a system of voting by shareholders for the election of directors at a session of the shareholders assembly in which the shareholder can multiply his voting rights by the number of candidates and vote them all for one candidate for director or supervisor.

56 Company Law of the People's Republic of China, adopted at the $18^{\text {th }}$ Meeting of the Standing Committee of the Tenth National People's Congress of the People's Republic of China on 27 October 2005, effective on 1 January 2006, Art. 106.

57 Id. Art. $21 \&$ Ch. VI.

58 Id. Art. 152. See also Hui Huang, Shareholder Derivative Litigation in China: Empirical Findings and Comparative Analysis, 27(4) Banking and Finance Law Review 619 (2012).

59 Company Law of the People's Republic of China, Art. 20.

60 Id. Art. 34.

$61 \quad$ Id. Art. 181. 
at least a third of the board, ${ }^{62}$ majority power remains extremely concentrated. ${ }^{63} \mathrm{As}$ a result, the ability of independent directors to influence the overall strategy of the company remains limited.

The Chinese system of governance is loosely based on German governance with a quasi two-tier structure of the board with a board of directors and a supervisory board. Although the 2006 Company Law has clarified the role of the supervisory board to a large extent, certain shortcomings still remain. In practice, the role of the supervisory board is restricted to rubber-stamping the decisions of the board of directors, which is the main decision-making authority. The duplication and overlapping of functions results in redundancy in the corporate governance structure. This increases adminitrative costs and dilutes the authority of the board of directors. ${ }^{64}$

Directors are crucial to the commercial performance of corporations and are held accountable for the conduct and activities of corporations. They have also been subject to increasing legal responsibilities. ${ }^{65}$ The powers of managing corporations are vested in the board of directors. Since the power of management is conferred on the board, the members' meeting cannot direcly interfere with the management of the corporation. However, it may be indirectly influenced through the power to alter the constitutional documents of the company and the power to appoint or remove the directors. This arrangement allows the directors to assume a dominant role in the company and raises the issue of probable misuse of this power by the directors. This, in turn, underlines the need to enhance administrative oversight in the affairs of the company. This function is served by the non-executive and the independent directors that are in place to prevent the abuse of control over the management by the directors. ${ }^{66}$

In general, the fiduciary duties of directors consist of two threads, namely a duty of loyalty and a duty of care. However, in the earlier Chinese company law, 1993, only the concept of good faith could be located. A duty of care was absent. ${ }^{67}$ The directors were only under an obligation to faithfully discharge their duties and work in the interest of the company and not be motivated by personal gain by misusing their

62 China Securities Regulatory Commission, Guidelines for Introducing Independent Directors to the Board of Directors of Listed Companies, Zhengjianfa [2001] No. 102 (Jan. 4, 2020), available at http:// www.csrc.gov.cn/pub/csrc_en/newsfacts/release/200708/t20070810_69191.html.

63 Feinerman 2007.

64 IIF Equity Advisory Group, Corporate Governance in China - An Investor Perspective (March 2006).

65 Yuwa Wei, Director's Duties Under Chinese Law: A Comparative Review, 3(1) University of New England Law Journal 31 (2006).

66 Id.

${ }^{67}$ M 176, Documents and Studies on $19^{\text {th }} \mathrm{c}$. Monetary History, When Orient and Occident Meet, Proceedings of the Round Table of the "Silver Monetary Depreciation and International Relations" Program (ANR DAMIN, LabEx TransferS), Osaka, April 4-6, 2014 (G. Depeyrot (ed.), Wetteren: Moneta, 2014) (Jan. 4, 2020), available at http://ssrn.com/abstract=2449299. 
position. Any personal engagement or assisstance in the operations of a competing company, which might be detrimental to the interests of the company on the board of which they served, was prohibited. The new Companies Act 2005 introduced the concept of duty of care. The result is the express commitment to uphold duty of loyalty and care to the companies by the directors, supervisors and senior officers of Chinese companies.

Under Chinese law, a person shall not take the position of a director, a supervisor or any senior officer of a company if he has no or only limited civil capacity, if it is less than five years since the expiration of the term of enforcement of a criminal punishment that was imposed on him for corruption, bribery, conversion or misappropriation of property, or disruption of the order of the socialist market economy, or it is less than five years since the expiration of the term of enforcement of a punishment that deprived him of his political rights for a crime he had committed, if it is less than three years since the completion of the liquidation of a company or enterprise that became bankrupt and went into liquidation and for the bankruptcy of which he was held personally liable as a director of the board, factory director or manager of such company or enterprise. ${ }^{68}$ Article $148^{69}$ of the Company Law of the People's Republic of China 2005 provides that the directors shall abide by the laws, administrative regulations and the articles of association of the company and show their loyalty towards the company.

Under the provisions of Article 149 of the Company Law of the People's Republic of China 2005 directors are subject to a number of restrictions, such as misappropriation of funds or the deposit of funds of the company in bank accounts opened in their own names or in the names of others. ${ }^{70}$ Lending funds and entering into contracts in violation of the articles or without the approval of shareholders are prohibited as well. Directors are not allowed to take advantage of their positions to obtain for their own benefit or the benefit of others any business opportunities that belong to the company or to engage in the same type of business as that of the company for their own account or for the account of others without approval of the shareholder meeting or the shareholder general meeting. They are also not allowed to disclose any secrets of the company without authorization. Additionally, if a director, a supervisor or a senior officer violates any provisions of the laws or administrative regulations or the articles of association of the company in the performance of his official duties, thus causing any losses to the company, he shall be liable for compensation for

68 Company Law of the People's Republic of China, Art. 147.

69 "The directors, supervisors and senior officers of a company shall abide by laws, administrative regulations and the articles of association of the company and owe duties of loyalty and diligence to the company. The directors, supervisors and senior officers shall not take advantage of their functions and powers to accept bribes or seek other illicit gains, nor shall they convert any property of the company."

70 Company Law of the People's Republic of China, Art. 149. 
such losses. ${ }^{11}$ If any director or senior officer is in violation of any provision of laws, administrative regulations or the articles of association of the company, thus causing any losses to the shareholders, the shareholders may initiate legal proceedings against such director or senior officer in the people's court. ${ }^{22}$

Another important distinguishing factor in the Chinese Company Law is that Chinese corporations embrace the mechanisms of both the supervisory board and the independent directors appointed to the board. ${ }^{73}$ The practice of appointing independent directors to the boards of listed companies is prompted by the CSRC, which is the regulator of securities transactions and markets in China. The Guidelines for Introducing Independent Directors to the Board of Directors of Listed Companies were introduced by the CSRC in 2001 with the Code of Corporate Governance introduced in the following year. The board should have at least one-third independent directors as per the new Guidelines. ${ }^{74}$ Training classes for independent directors were organized by the CSRC. An audit committee was also recommended. ${ }^{75}$ The audit committee is required to $(a)$ recommend the engagement or replacement of the company's external auditing institutions; $(b)$ review the internal audit system and its execution; (c) oversee the interaction between the company's internal and external auditing institutions; (d) inspect the company's financial information and its disclosure; and (e) monitor the company's internal control system. ${ }^{76}$ This marks the successful inclusion of independent directors in the listed companies by the amended Company Law.

A review of China's securities market shows that in December 2006 there were 1,461 companies listed in China. ${ }^{77}$ There were over 65 million investor accounts (5 percent of the population), 118 securities firms and dozens of fund management firms in China as of mid-2003. ${ }^{78}$ As for the regulatory system, the CSRC, established in 1992, oversees all the securities business activities in China (including futures). The original Securities Law, enacted in July 1999 and significantly amended in 2005 along with the revised Company Law, provides a legal framework for securities regulation. Legal reforms protecting shareholder rights through lawsuits, accounting reform and supervision of auditors have also been promoted by the CSRC. As noted

71 Company Law of the People's Republic of China, Art. 150.

72 Id. Art. 153.

73 Wei 2006

74 Guidelines for Introducing Independent Directors, supra note 62, Art. I, para. 3.

75 China Securities Regulatory Commission, Code of Corporate Governance for Listed Companies in China, Zhengjianfa No. 1 of 2002, Art. 6, para. 52 (Jan. 4, 2020), available at http://www.csrc.gov.cn/ pub/csrc_en/newsfacts/release/200708/t20070810_69223.html.

76 Id. Art. 6, para. 54.

77 Feinerman 2007.

78 Wei 2006. 
above, one of the chief policies of the CSRC regulation was to increase the number of independent directors on company boards.

The similarity in the perception of problems, and the broad routes to tackling them, with the Western economies is a prominent aspect of corporate governance in China. The complicating factor, however, is that a great deal of political control by the Chinese Communist Party over the companies still remains under the facade of a capitalistic structure. The distinctive feature of the two-tier board system clearly exhibits borrowing from the corporate and legal life of countries like Germany. ${ }^{79}$ When compared with the law in the USA and the UK, Chinese law has much room for development. Despite China's tradition of centralization and government regulation, the law hardly regulates executive compensation at all..$^{80}$ The Company Law treats it entirely as an internal corporate issue, only providing that compensation of directors and supervisors shall be decided by the shareholder meeting and that compensation of executives shall be decided by the board of directors. ${ }^{81}$ After recent revisions, the law prohibits companies from offering loans directly or indirectly through subsidiaries to directors, supervisors and executives..$^{82}$ It also requires that companies disclose the compensation of directors, supervisors and executives regularly, similar to provisions of the U.S. Sarbanes-Oxley Act of 2002. ${ }^{83}$ Yet, there have been no implementing rules promulgated by the State Council, the CSRC or other relevant government agencies. ${ }^{84}$

China's rapid economic progress would not have been possible without corresponding legal reforms. China's 2005 Company Law represents a major step towards achieving international standards of business organization and motivation. Although China's legal reforms can be further improved, in many respects what took mature capitalistic legal systems several centuries to develop has been accomplished by China in under two decades. China has had the advantage of being able to learn and borrow ideas from the experience of others overseas. ${ }^{85}$

More than a thousand state-owned enterprises (SOEs) were privatized through share-issuance privatization on two primary stock exchanges - the SHSE and the SZSE during the 1990s by the Chinese government. This is a part of the central strategy of the Chinese government towards creating a "modern-enterprise system.196

79 Liu 2005

80 Feinerman 2007.

81 Company Law of the People's Republic of China, Art. 38.

82 Id. Art. 117.

83 Id. Art. 118.

84 Feinerman 2007.

85 Ong \& Baxter 1999.

86 Henk Berkman et al., Agency Conflicts, Expropriation and Firm Value: Evidence from Securities-Market Regulation in China (Jan. 4, 2020), available at http://ssrn.com/abstract=420763. 
There are two types of blockholders in China. The State maintains control over the majority of the nation's listed firms and this is reflective of the "socialist Chinese market economy." The shares are held by the State in the form of State shares. The other type of blockholder is the domestic corporations and other non-individual legal persons that own the Legal-Person (LP) shares. This includes listed companies, non-bank financial institutions and state-controlled enterprises with at least one non-state owner. Since the State and LP shares are not publically tradeable they cannot be owned by foreign investors, but can only be transferred to domestic corporations with the prior approal of the CSRC. Tradeable-A shares, typically held by individuals and domestic corporations, are the only type of equity that can be traded on the stock market. ${ }^{87}$

The horizon of corporate governance has expanded from mitigating the agency problem between the directors and the minority shareholders to protecting the shareholders from the blockholder and their management team, i.e. the directors. ${ }^{88}$ There was a major legal convergence that occurred in China when the CSRC introduced new regulations aimed at reducing expropriation from minority shareholders by the controlling blockholders. Three regulations were introduced in the second quarter of 2000 that were to some extent motivated by China's successful attempt to gain entrance into the World Trade Organisation. The first regulation significantly increased the rights of the minority shareholders at a firm's annual shareholder (general) meeting. The new regulation also prohibited shareholders involved in related-party trading (transactions) from voting on related-party trading (transactions). The second regulation prohibited the issuance of loan guarantees by a firm to its controlling shareholder, and the third regulation improved transparency and regulation of asset transfers to related parties.

\subsection{India}

India follows a corporate governance system that is a hybrid of the outsiderdominated, market-based systems of the United Kingdom and the United States and the insider model. ${ }^{89}$ The outsider model displays dispersed share ownership with large institutional shareholdings. ${ }^{90}$ The concept of separation of ownership and control ensures that the role of the directors in control of a company is placed higher than the individual opportunism of shareholders. This model is called the outsider model because shareholders typically have no interest in managing the company and retain no relationship with the company except for their financial investment.

87 Berkman et al., supra note 86.

88 Henk Berkman et al., Political Connections and Minority Shareholder Protection: Evidence from Securities Market Regulation in China, 45(6) Journal of Financial and Quantitative Analysis 1391 (2010).

89 Sarkar \& Sarkar 2000.

90 Varottil 2009. 
At the same time, the appointment or removal of directors proves to be difficult on an individual basis, due to the costs involved in coordination of large numbers of dispersed shareholders.

On the other hand, a close-knit group of shareholders wielding considerable voting rights in a general meeting of shareholders gives rise to the insider model. Such insiders would also have an increased long-term relationship with the company. With the remainder of the shareholding being diffused and held by institutions or individuals constituting the public, insiders naturally tend to have a controlling interest in the company. By virtue of being able to appoint and remove directors at will, they possess the ability to exercise dominant control over the company's affairs. As to the identity of the controlling shareholders, they tend to be mostly business family groups or the State.

A number of committees have been established over time to recommend measures to improve corporate governance, investor protection, independent audit, etc., in the country. ${ }^{91}$ The recommendations of these committees and other stakeholders culminated in the enactment of the Companies Act 2013 - possibly the single most important development in India's history of corporate legislation, next only to the Companies Act 1956 which it replaces.

The Companies Act 2013 provides for a number of corporate governance reforms which were hitherto absent in the previous 1956 iteration..$^{92} \mathrm{~A}$ third of the board of listed companies must be independent directors if the chairman of the board is a non-executive member. In the event that the chairman is an executive member, half of the board is required to be independent. ${ }^{93}$ Fresh out of the Satyam Computer Services accounting scandal, ${ }^{94}$ the qualifications and liability of independent directors were revamped. Independent directors must possess integrity, relevant expertise and experience, and they must not be connected to the company or its associate or subsidiary companies as a past promoter, director, nor so too any of

91 Balasubramaniam, supra note 28.

92 Although most of these norms were previously present as part of the Bombay Stock Exch. Equity Listing Agreement.

93 Companies Act 2013, sec. 149.

94 In January 2009, Mr Ramalinga Raju, the promoter of Satyam Computer Services (Satyam), one of India's largest information technology companies, voluntarily confessed, in his resignation letter to the board of directors, to major financial wrong-doings committed by him over the years to inflate profits. This included, inter alia, showing inflated revenues, non-existent debtors and earnings from interest in the magnitude of Rs 7,000 crores (approximately US\$1.4 billion). See fuBureau, It Was Like Riding a Tiger, Not Knowing How to Get off Without Being Eaten, The Financial Express, 9 January 2009 (Jan. 4, 2020), available at http://www.financialexpress.com/news/it-was-like-riding-a-tiger-not-knowing-how-toget-off-without-being-eaten/407917; Mandar Nimkar, How Much Is Satyam's Stock Actually Worth?, The Economic Times, 7 January 2009 (Jan. 4, 2020), available at https://economictimes.indiatimes.com/tech/ software/how-much-is-satyams-stock-actually-worth/articleshow/3948051.cms; Heather Timmon \& Jeremy Kahn, Indian Company in a Fight to Survive, The New York Times, 8 January 2009 (Jan. 4, 2020), available at http://www.nytimes.com/2009/01/09/business/worldbusiness/09outsource.html. 
their relatives. ${ }^{95}$ Independent directors cannot have had a pecuniary relationship in the company, its holding, subsidiary or associate company, or their promoters, or directors, during the two immediately preceding financial years or during the financial year of appointment. The Companies Act 2013 also provides for a code of conduct that independent directors are expected to adhere to. ${ }^{96}$

The Companies Act 2013 also provides for the creation of three board committees. The Audit Committee ${ }^{97}$ must be composed of at least three financially educated directors out of which independent directors are in the majority. The terms of reference for the Audit Committee include the recommendation for appointment, remuneration and terms of appointment of the auditors of the company, review and monitoring of the auditors' independence and performance, and effectiveness of the audit process, examination of the financial statement and the auditors' $r e p o r t$ thereon, and scrutiny of inter-corporate loans and investments. Similar to the Audit Committee, the Nomination and Remuneration Committee ${ }^{98}$ must also be composed of three or more non-executive directors of which the majority shall be independent directors. The duties of the Nomination and Remuneration Committee include identification and recommendation of appropriate senior management and directors to the board, and the committee must formulate a policy to provide for the appointment and remuneration of directors, key managerial personnel and other employees. A Stakeholder Grievance Committee must also be set up to resolve grievances of the security holders of the company. While the minimum strength for the committee is not provided for, the chairman must be a non-executive director.

Independent and objective boards committed to the welfare of the company and equitable treatment to all its shareholders is the cornerstone of good corporate governance. The 2013 initiatives have strengthened many existing regulatory requirements and introduced some new ones, too. ${ }^{99}$ For the first time, the Companies Act 2013 enumerates the qualifying criteria both in affirmative and in negative terms. In affirmative terms, the person should, in the board's opinion, be one of integrity and possess relevant expertise and experience or should possess such other prescribed qualifications (in other words, should be a fit and proper person). ${ }^{100}$

In negative terms, a number of restrictions apply to the appointment of independent directors in India. The proposed independent director should not be a promoter of the company or its holding, subsidiary or associate company or related to promoters or directors of the company, its holding, subsidiary or associate

\footnotetext{
95 Companies Act 2013, sec. 149.

96 Id. sec. 149(8) \& sch. IV.

97 Id. sec. 177.

98 Id. sec. 178.

99 Balasubramaniam, supra note 28.

100 Companies Act 2013, sec. 149(6).
} 
company nor should he have any pecuniary relationship with the company, its holding or subsidiary or associate companies or their promoters or directors during the current or immediately preceding two financial years. There should not be (or have been) a pecuniary interest of his relatives amounting to 2 percent or more of the gross turnover or total income or 50 lakhs rupees ( 5 million rupees) or such higher amount as may be prescribed, whichever is lower, during the current or immediately preceding two years, or in whatever capacity in the holding company or its subsidary or associate companies, or directors. Neither should the proposed independent director hold 2 percent or more, together with his relatives, of the voting power in the company, nor should he have served as the chief executive officer or director of any not-for-profit organization that receives 25 percent or more of its receipts from the company, any of its promoters, directors, its holding, subsidiary or associate company or that holds 2 percent or more of the total voting powerr of the company. ${ }^{101}$

A director of a company shall act in accordance with the articles of the company. He shall act in good faith in order to promote the objects of the company for the benefit of its members as a whole and in the best interest of the company, its employees, the shareholders, the community and for the protection of the environment. ${ }^{102} \mathrm{~A}$ director of a company shall exercise his duties with due and reasonable care, skill and diligence and shall exercise independent judgment; he shall not become involved in a situation in which he may have a direct or indirect interest that conflicts or possibly may conflict with the interests of the company; he shall not achieve or attempt to achieve any undue gain or advantage either to himself or to his relatives, and if found guilty of such he shall be punished by the imposition of an amount equal to that gain.

Outside independent directors can attend to the corporate governance concern of controlled entities in their monitoring role. This is particulary important in jurisdictions like India where the minority stockholders have limited legal rights. Business decisions that wrongfully benefit the controlling stockholders at the expense of the minority shareholders can be impeded by the independent directors in controlled entities. ${ }^{103}$ Where the directors have only limited power to decide issues without the consent of the controlling shareholders, independent directors can publicize or threaten to publicize majority shareholder abuses. This acts as an additional mechanism to protect the interests of the minority shareholders.

As a direct result of the Satyam case, provisions relating to auditor appointment and liability have been tightened as well. An individual auditor can be appointed for one term of five years and an audit firm for two terms of five years each. ${ }^{104}$ In addition,

Balasubramaniam, supra note 28.

Companies Act 2013, sec. 166.

Afsharipour 2011.

104

Companies Act 2013, sec. 139.
} 
the partner and team of an audit firm engaged in the audit of a company must be changed every year. A successive reappointment of the audit firm subsequent to the initial appointment requires a cooling-off period of five years, and the incoming and outgoing firms should not have common partners. Auditors are prohibited from providing non-audit services including accounting and book keeping services, internal audit, design and implementation of any financial information systems, actuarial services, investment advisory services, investment banking services, rendering of outsourced financial services or management services to companies for which they have been engaged as an auditor. ${ }^{105}$ Auditors should not hold any interest in the company or its subsidiaries, be indebted to it, have any business interest with the company or have a relative who is a director of that company. ${ }^{106}$

Listed companies, companies with a paid-up share capital of 100 million rupees and companies with loans of more than 250 million rupees must appoint an internal auditor to evaluate the functions and activities of the company. ${ }^{107}$ While the internal audit is required to be conducted under the aegis of the Audit Committee, internal auditors are separate from the statutory auditors mentioned above. Such internal auditors may be a chartered or a cost accountant or other professional appointed by the board, which may also engage an external agency.

The concept of the class action suit has been introduced in the aftermath of the Satyam corporate scandal. ${ }^{108}$ While the law on class action suits is still in its infancy, the rationale given by the Ministry of Corporate Affairs for insertion of this provision was to see that "the shareholder feels like a king" in matters such as managerial remuneration. ${ }^{109}$ Traditionally, there are four kinds of class action suits that can arise against a company, namely product liability or personal injury class actions, consumer class actions, employment class actions and securities class actions, but in India the right to file a class action suit under Section 245 of the Companies Act 2013 is only given to shareholders and depositors. ${ }^{110} \mathrm{It}$ is imperative that for a class action suit to arise there must be one or more legal or factual claims common to the entire class; the representative parties must adequately protect the interests of the class, the class must be so large as to make individual suits impractical; and

105 Companies Act 2013, sec. 144.

106 Id. sec. 141.

107 Id. sec. 138.

108 Id. sec. 245 .

Class Action Suits to Ensure Shareholder Democracy, The Hindu, 8 November 2009 (Jan. 4, 2020), available at http://www.thehindu.com/todays-paper/tp-business/class-action-suits-to-ensureshareholder-democracy/article134987.ece.

110 Minny Narang \& Gunjan Jain, Class Action Suits: A Measure of Progressive Activism in India, 2(12) Paripex - Indian Journal Of Research 49 (2013) (Jan. 4, 2020), also available at http://theglobaljournals. com/paripex/file.php?val=December_2013_1388040512_75c39_16.pdf. 
the claims or defenses must be typical of the plaintiffs or defendant. Grounds for filing a class action suit in India include an act which is ultra vires or a breach of the constitutional documents of the company, fraudulent, unlawful or wrongful act or omission or conduct by the directors, auditors or experts engaged by the company."11 While the provisions relating to class action suits in India seem to have been inspired by the U.S. Federal Rules of Civil Procedure, ${ }^{112}$ class actions in the United States have been around for a while and are more sophisticated. Certain aspects including an opting-out clause or an enabling provision for a lead plaintiff or even consumer class actions are missing in Indian class action provisions.

\section{Convergence in the Positions of India and China}

Adrian Cadbury, the former head of the Committee on the Financial Aspects of Corporate Governance in the United Kingdom, defined corporate governance as "the system by which companies are directed and controlled." ${ }^{113}$ This definition, however, leaves unanswered the important question: For whose benefit should a company be run? There are two major schools of thought on this issue. ${ }^{114}$ One, sometimes called "shareholder theory," asserts that the primary goal of corporate governance should be to protect investors against expropriation by management. ${ }^{115}$ The other approach is often referred to as "stakeholder theory." It treats corporate governance in a broader context, and asserts that corporate governance should consider not only the investors' interests, but also the interests of other stakeholders such as employees, customers, suppliers and communities, which might be affected directly or indirectly by companies' behaviors. ${ }^{116}$

Because of the differences in the approaches of China and India to economic growth, differences in their approaches to corporate governance exist as well. In India, corporate governance reform was built on the existing framework which had been in place since 1956. It started with the private sector and was expanded to the public sector. In China, it worked the other way around, simply because initially there were few truly privatized enterprises. This difference in the starting point of corporate governance reforms would have had certain repercussions for how the

\footnotetext{
111 Companies Act 2013, sec. 245.

112 Fed. R. Civ. P. 23.

113 Cadbury 1992.

114 See G. Mitu Gulati et al., Connected Contracts, 47 UCLA Law Review 887 (2000) and Stephen M. Bainbridge, The Politics of Corporate Governance: Roe's Strong Managers, Weak Owners, 18(3) Harvard Journal of Law \& Public Policy 671, 681-682 (1995).

115 Andrei Shleifer \& Robert W. Vishny, A Survey of Corporate Governance, 52(2) Journal of Finance 737 (1997).

116 Gerard J. Charreaux \& Philippe Desbrieres, Corporate Governance: Stakeholder Value Versus Shareholder Value, 5(2) Journal of Management \& Governance 107 (2001).
} 
reforms occurred and what shape they are likely to take in the future. ${ }^{117}$ While the initial ownership structures in Chinese and Indian corporations are different in only that one is owned by the State and the other by the family, in more recent times the corporate rules that apply to these nations seem to have a number of common features as well.

Both countries provide for independent directors having similar requirements for qualifications as well as conduct. The Chinese Company Law 2005 does not have provisions relating to board committees. However, China follows the two-tier board system inherited from Germany, while India follows the common law approach of a single board. While both countries provide for an external audit of the books of accounts of companies, the Indian Companies Act 2013 delves into details such as auditor rotation, restricted mandates and liability in far more detail. Given that the Indian provisions relating to company auditors stem as a direct result from recent past experience, this seems to suggest that the development of corporate governance norms are indeed path-specific.

However, what is interesting to note is that there has been a convergence in terms of their corporate governance reforms which are based on Anglo-American models. Both countries face intense competition for capital as well as products from each other. ${ }^{118}$ Referring to earlier sections of this paper, both countries have greater protection for minority shareholders, increased customization of company constitutional documents, requirements of an independent board, enhanced disclosure, more expectations from board committees and increased obligations on executive directors.

In both India and China the concept of independent directors is prevalent. This is again reiterated in the Code for Independent Directors in India which stipulates that independent directors shall safeguard the interests of all stakeholders and balance the conflicting interests of the stakeholders. ${ }^{119}$ However, in China independent directors are sometimes described as non-executive directors or outside directors..$^{20}$ The CSRC, the regulatory body over securities transactions and securities markets, promotes the practice of appointing independent directors to listed companies' boards. The CSRC produced the Guidelines for Introducing Independent Directors to the Board of Directors of Listed Companies in 2001. In the following year, it promoted the Code of Corporate Governance for Listed Companies. Since 2003, according to the

117 Lucian A. Bebchuk \& Mark J. Roe, A Theory of Path Dependence in Corporate Ownership and Governance, 52(1) Stanford Law Review 127 (1999).

118 Ian Coxhead \& Sisira Jayasuriya, The Rise of China and India and the Commodity Boom: Economic and Environmental Implications for Low-Income Countries (2008) (Jan. 4, 2020), available at http://www.aae. wisc.edu/coxhead/papers/gdn/gdn-8.pdf. See also Tirupati N. Srinivasan, China and India: Economic Performance, Competition and Cooperation: An Update, 15(4) Journal of Asian Economics 613 (2004).

119 Balasubramaniam, supra note 28.

120 Wei 2006. 
Guidelines and the Code, the boards of all listed companies should have at least onethird independent directors, and there are similar provisions ${ }^{121}$ in India as well.

In China, the directors are prevented from being involved in transactions that result in conflicts of interest and engaging in business that competes with the company. The stipulation is merely that directors should not enter into a contract or have transactions with the company unless such transactions are permitted by the constitutional documents of the company or approved by the shareholder meeting. ${ }^{122}$ Similar provisions can be found in India in the Companies Act 2013. ${ }^{123}$ Chinese law does not address the issue of disclosure of interest by directors nor the issue of whether a director could be present and vote on the matter at the shareholder meeting if the director was also a shareholder. ${ }^{124}$

In both India and China the minority shareholders enjoy a moderate level of protection. This is mainly because in India the minority shareholders do not have much of a say, as they do not hold the sufficient number of shares in the company to be in a position to outvote or even veto the decisions in the sphere headed by the controlling shareholders. ${ }^{125}$ The dominant shareholders often improve their position in the company by seeking control and voting rights in excess of the shares they hold. In other words, their control rights far exceed their economic interests in the company. ${ }^{126}$ With respect to China, the State wants the enterprises it controls absolutely and owns partially to be run efficiently, but not solely for the purpose of shareholder wealth maximization. A necessary element of state control of an enterprise is the use of that control for purposes other than the maximization of wealth (as shareholder purposes are), such as the maintenance of urban employment levels, direct control over sensitive industries, effective price control in a given sector, politically motivated job placement or extraction of profits for politically privileged insiders. ${ }^{127}$ But in using its control for these purposes, the State openly and not

121 Clause 49 of the listing agreement provided that the board of directors of the listed company must have a minimum number of independent directors. Where the chairman is an executive or a promoter or related to a promoter or a senior official, then at least one-half the board should comprise independent directors; in other cases, independent directors should constitute at least one-third of the board size. Bombay Stock Exch. Equity Listing Agreement, Cl. 49(I)(A) (Jan. 4, 2020), available at https://www.bseindia.com/downloads1/ListingAgreement_30092014.pdf.

Donald C. Clarke \& Nicholas C. Howson, Pathway to Minority Shareholder Protection: Derivative Actions in the People's Republic of China, GW Law Faculty Publications \& Other Works, Working Paper No. 1064 (August 2011) (Jan. 4, 2020), available at https://scholarship.law.gwu.edu/faculty_publications/1064. 
necessarily fraudulently exploits minority shareholders who have no other way to benefit from their investment. As long as state policy requires the State to remain an active controlling investor in firms of which it is not the sole shareholder, meaningful legal protection for minority shareholders will mean either constraints on the state's ability to do precisely those things for which it has retained control, or else a de facto separate legal regime (at least as far as minority shareholder rights are concerned) for enterprises in which the State is the dominant shareholder.

\section{The Case for Divergence}

This paper notes in previous sections how India and China follow similar norms of corporate governance inspired by the Sarbanes-Oxley Act and the Cadbury Committee Report. However, in recent times there has been some resistance to this transplantation. The broad features of corporate governance norms that have been transplanted from other jurisdictions such as the USA and the UK follow the "outsider" model of corporate governance and hence those norms are not likely to be suitable for implementation in addressing governance problems in India and China, which both follow the "insider" model. It is amply clear from recent events involving the collapse of several leading financial institutions due to large-scale corporate governance failures, at least indirectly, that they have been the result of the failure of the efficacy of the U.S. and UK norms of corporate governance in India. ${ }^{128}$

This distinction between insider and outsider models of business stems from the existence or the lack of concentrated shareholding in companies. Berle and Means' seminal work of 1932 drew our attention to what was considered the modern structure of the corporation - that of widespread and dispersed shareholding and power concentrated in the hands of managers elected by these same shareholders. Coordination and other transaction costs between shareholders meant that managers, acting as agents, ought to be subject to a strict code of conduct, so as not to indulge in self-dealing opportunism. Thus, the importance and application of the agency problem as between shareholders and managers has been highlighted in prevalent literature. ${ }^{129}$

However, the phenomenon of widespread ownership seems to be restricted to a few countries. Except in economies with very good shareholder protection, relatively few of these firms are widely held, in contrast to Berle and Means's image

128 Varottil 2009.

129 Michael C. Jensen \& William H. Meckling, Theory of the Firm: Managerial Behavior, Agency Costs and Ownership Structure, 3(4) Journal of Financial Economics 305 (1976). See also Henry Hansmann \& Reinier Kraakman, Agency Problems and Legal Strategies in The Anatomy of Corporate Law: A Comparative and Functional Approach 21 (R. Kraakman et al. (eds.), Oxford: Oxford University Press, 2004). See also Shleifer \& Vishny 1997; Rafael La Porta et al., Investor Protection and Corporate Governance, 58(1-2) Journal of Financial Economics 3 (2000). 
of ownership of the modern corporation. ${ }^{130}$ Rather, these firms are typically controlled by families (as in the case in India) or the State (as in the case of China). ${ }^{131}$ In contrast, firms in the USA are generally considered to have a widespread and dispersed shareholding. ${ }^{132}$ Nevertheless, this phenomenon of widespread ownership of U.S. firms has been called into question. ${ }^{133}$

One of the hallmarks of corporate governance is the protection of the rights of shareholders against the opportunism of entities and individuals that are the "insiders" of the firm. The question then arises: Against whom are these rights to be upheld? In companies with widespread and dispersed shareholding, considerable power is vested in the managers. On the other hand, in companies with concentrated shareholding, power is vested in the majority shareholders. These majority shareholders, by virtue of their level of ownership in the firm, therefore control the board and its managers. The identity of the "insider" therefore changes between companies with dispersed and concentrated shareholding. This brings about the second agency problem, namely that between majority and minority shareholders. ${ }^{134}$

One of the goals of corporate governance norms in the USA and the UK has been to reduce agency costs between shareholders and managers, thus striving to resolve the agency problem. However, most corporate governance norms in the USA and the UK fail to make a distinction between minority shareholders who have little or no say in how the company is to be run and majority shareholders who not only control the board, but may also take up key managerial positions within the company. A case in point is that of independent directors. As a concept, independent directors bring a broader view to the company's activities and protect shareholder interests against members of the board itself, and take the lead in cases of potential conflicts of interest for members of the board. ${ }^{135}$ Generally, independent directors are required not to have any material relationship with the company. ${ }^{136}$

However, in companies with concentrated shareholding it is possible for independent directors to lose some of their independence. Majority shareholders

130 See generally Adolf A. Berle \& Gardiner C. Means, The Modern Corporation \& Private Property (New Brunswick, N.J.: Transaction Publishers, 1991).

131 La Porta et al. 2000.

132 Berle \& Means 1991.

133 Clifford G. Holderness, The Myth of Diffuse Ownership in the United States, 22(4) Review of Financial Studies 1377 (2009) (96 percent of U.S. firms have blockholders; these blockholders in the aggregate own an average 39 percent of the common stock. The ownership of U.S. firms is similar to and by some measures more concentrated than the ownership of firms in other countries).

134 Hansmann \& Kraakman 2004.

135 Cadbury 1992. See also Confederation of Indian Industry, Desirable Corporate Governance: A Code (1998) (Jan. 4, 2020), available at http://www.nfcg.in/UserFiles/ciicode.pdf.

136 N.Y.S.E. Listed Company Manual, 303(A.02) (2013). See also Bombay Stock Exch. Equity Listing Agreement, cl. 49. 
are virtually able to appoint and replace the entire board and, through this, influence management strategy and the operational affairs of the company. Thus, management, including independent directors, will likely owe its allegiance to the controlling shareholders. ${ }^{137}$

As recently as October 2016, an example of this influence that majority shareholders wield over the management of the company surfaced in respect of the Tata group of companies, one of India's largest family-run conglomerates. The Tata group comprises over 100 companies including 29 listed ones which account for 7.5 percent of the market capitalization of the Bombay Stock Exchange. ${ }^{138}$ With more than US\$100 billion in combined annual revenue, it also includes UK-based Jaguar Land Rover Automotive PLC and Tetley. ${ }^{139}$ Companies of the Tata group are held directly or indirectly by Tata Sons, an unlisted company, which in turn is closely held by a number of family trusts, which are controlled by Ratan Tata to the extent of 65 percent of the shareholding of Tata Sons. ${ }^{140}$

In 2013, Ratan Tata stepped down as chairman of Tata Sons, making way for Cyrus Mistry. In an astonishing development a mere four years later Mistry was unceremoniously removed not just as chairman but from the board of a number of listed subsidiaries of the Tata group, on the directions of the Tata family trusts as the majority shareholders of Tata Sons. The reasons for this ouster included, at least on paper, the alleged incompetence on the part of Mistry. ${ }^{141}$ However, there seems to be evidence otherwise, with the independent directors of one Tata subsidiary company expressing their confidence in Mistry. ${ }^{142}$ Additionally, this move by the family trusts reveals a growing disagreement over the overall future strategy of the group between Mistry and Ratan Tata, who retains the controlling interest in the

137 Varottil 2009.

138 Raghuvir Srinivasan, Mistry's Ouster, An Unseemly Affair, The Hindu Business Line, 25 October 2016 (Jan. 4, 2020), available at http://www.thehindubusinessline.com/opinion/explaining-cyrus-mistrysouster-and-tata-groups-future/article9267887.ece.

139 Santanu Choudhury, What Ratan Tata's Letter to Tata Group Employees Said About Cyrus Mistry's Departure, The Wall Street Journal (India), 2 November 2016 (Jan. 4, 2020), available at http://blogs. wsj.com/indiarealtime/2016/11/02/what-ratan-tatas-letter-to-tata-group-employees-said-aboutcyrus-mistrys-departure/.

140 M.K. Venu, Were Cyrus Mistry's Powers Curtailed? Tatas Will Have to Answer Many Questions, Business Standard, 29 October 2016 (Jan. 4, 2020), available at http://www.business-standard.com/article/ companies/were-cyrus-mistry-s-powers-curtailed-tatas-will-have-to-answer-many-questions116102600377_1.html.

141 Clash of The Tatas, The Economist, 19 November 2016 (Jan. 4, 2020), available at http://www. economist.com/news/business/21710304-indias-biggest-firm-adds-internal-strife-its-long-listproblems-clash-tatas.

142 The Indian Hotels Co. Ltd., Corporate Filing, 4 November 2016 (Jan. 4, 2020), available at https:// www.bseindia.com/xml-data/corpfiling/CorpAttachment//2016/11/A5B5B9AB_E91E_471F_8ACD_ FED5E7566EDA_182411.pdf. 
family trusts and therefore Tata Sons and eventually the Tata group. ${ }^{143}$ In a letter to the shareholders of a number of Tata group companies, Mistry highlighted a number of instances of the allegedly improper involvement of the majority shareholders of Tata Sons in the operations of not just the company but also its subsidiaries. ${ }^{144}$

While the legality of the removal of Mistry is presently a matter for the National Company Law Tribunal, ${ }^{145}$ this incident underscores the failure of "inspired" corporate governance norms in India. While Tata Sons remains unlisted, some commentators have highlighted the greater governance issue, especially for a company that controls a large number of publically listed companies ${ }^{146}$ which, therefore, are subject to public shareholder protection norms.

There are other forms of shareholder protection that have been inspired by the Cadbury Committee Report or Sarbanes-Oxley that suffer from the same predicament. While the Chinese Company Law 2005 does not have provisions relating to board committees, ${ }^{147}$ the Indian Companies Act 2013 does. The provisions for board committees in both China and India require that such committees be constituted by a majority of independent directors and be chaired by independent directors. ${ }^{148}$ The functioning of such board committees is dependent on independent directors. ${ }^{149}$ If independent directors are not truly independent, it is possible for board committees to fail in carrying out their mandate. As the Tata-Mistry story so far has shown us, the reality is that independent directors continue to operate in the shadow of the promoters. ${ }^{150}$

143 Ratantrum, The Economist, 19 November 2016 (Jan. 4, 2020), available at http://www.economist. com/news/leaders/21710259-one-asias-most-important-firms-has-descended-chaos-its-patriarchratan-tata-largely.

144 BS Web Team, Full Text of Cyrus Mistry's Letter on the Issue of Transparency at Tata Trusts, Business Standard, 5 December 2016 (Jan. 4, 2020), available at http://www.business-standard.com/ article/companies/full-text-of-cyrus-mistry-s-letter-on-the-issue-of-transparency-at-tata-trusts116120501237_1.html.

ET Bureau, Cyrus Mistry Takes Tata Group to Court, Moves Company Law Tribunal Claiming Oppression, The Economic Times, 21 December 2016 (Jan. 4, 2020), available at http://economictimes.indiatimes. com/news/company/corporate-trends/cyrus-mistry-takes-tata-group-to-court-moves-companylaw-tribunal-claiming-oppression/articleshow/56085155.cms.

146 Umakanth Varottil, The Tata Sons Imbroglio: Whither Corporate Governance?, IndiaCorpLaw blog, 27 October 2016 (Jan. 4, 2020), available at http://indiacorplaw.blogspot.in/2016/10/the-tata-sonsimbroglio-whither.html.

147 Provisions for board committees in Chinese companies are found in the Code of Corporate Governance for Listed Companies in China.

Code of Corporate Governance for Listed Companies in China, cl. 52; Companies Act 2013, secs. 177178.

Cadbury 1992.

Umakanth Varottil, The Tata Episode: Corporate Governance and the Continuing Influence of Promoters, IndiaCorpLaw blog, 12 November 2016 (Jan. 4, 2020), available at http://indiacorplaw.blogspot. in/2016/11/corporate-governance-in-india-and.html. 
To date, most of China's biggest corporations remain closely held in the hands of the State. Similarly, Indian companies remain closely held in the hands of promoters and their families. The classic agency problem of separation of ownership and control is commonly associated with dispersed ownership. However, the secondary agency problem - that between majority and minority shareholders - comes into stark focus in companies with concentrated ownership.

It can be argued, of course, that on the positive side the foremost benefit of concentrated ownership of companies is that such entrenched ownership and control will offer strategic stability and longer-term sustainability, especially in the case of family-controlled entities. Concentrated shareholding also offers the prospect of more efficient and cost-effective management, the fruits of which would largely benefit the bottom line. There would be greater and closer managerial surveillance to preempt leakages at operational levels. The entrepreneurial drive to grasp business opportunities as they arise and convert them into profits is rarely as effective in non-family managerial structures that usually tend to get bogged down in ritualistic bureaucracy. On the other hand, this brings about issues of higher decisional power in the hands of the majority shareholder. This may lead to an entrenchment situation, ending in undertaking actions aimed at expropriating wealth from the rest of the minority shareholders.

Therefore, it is evident that in companies having a concentrated shareholder there is little need for protecting that shareholder from the very board that it controls. Rather, it is the minority shareholder who has little or no say on the board or in the manner in which the company is run that requires protection from the majority shareholder. By transplanting provisions of corporate governance from the USA and the UK perhaps both China and India have striven to resolve problems that did not exist in the first place. It is of course true that mechanisms to address the second agency problem exist - primarily through free transferability of shares, anti-oppression and mismanagement rules and provisions for class action suits. However, both in China and in India neither of these mechanisms is considered to be the mainstay of corporate governance norms. Perhaps the need then is for emerging economies such as China and India to develop and implement corporate governance norms that are separate from those of more developed economies.

\section{Conclusion}

We see how China and India have both had very different backgrounds with regard to the regulation of businesses. We have also seen how both nations have had, and continue to have, differences in who owns and thereby controls companies one being the State, the other the family. By all means, the two countries should have distinct models of corporate governance, given that their initial ownership structure and corporate regulation paths have been different. ${ }^{151}$

151 Bebchuk \& Roe 1999. 
But that has not been the case. An overwhelming majority of provisions relating to corporate governance are common between both countries. These provisions are rooted in "outsider" models of business, and questions as to the efficacy of such provisions in countries demonstrating a typically "insider" model of business have been raised. ${ }^{152}$ There is considerable evidence to show a growing concern that what may work for companies with dispersed shareholding may not similarly work for companies with a controlling shareholder. ${ }^{153}$

Through a comparative analysis of the (a) background of corporate law and jurisprudence, $(b)$ shareholding patterns and (c) extant corporate governance principles of India and China, this paper demonstrates how emerging economies run the risk of mitigating problems that are less likely to exist rather than dealing with issues that are more likely to exist when directly transplanting corporate governance norms from advanced economies. The opportunism of managers vis-à-vis shareholders is the norm in more advanced economies from which such norms have been transplanted. However, the same issue is of little concern when the role and powers of such managers is subordinate to shareholders having a controlling interest. Instead, a new issue of the opportunism of control versus minority shareholders arises in emerging economies such as China and India. This inter-shareholder opportunism is unlikely to exist in the absence of a controlling shareholder. This paper posits that emerging economies such as China and India ought to develop and implement corporate governance norms that are separate from those of advanced economies to combat the unique issues arising out of shareholding patterns at home.

\section{References}

Afsharipour A. Directors as Trustees of the Nation? India's Corporate Governance and Corporate Social Responsibility Reform Efforts, 34(4) Seattle University Law Review 995 (2011).

Bainbridge S.M. The Politics of Corporate Governance: Roe's Strong Managers, Weak Owners, 18(3) Harvard Journal of Law \& Public Policy 671 (1995). https://doi.org/ $10.2139 /$ ssrn. 275172

Bebchuk L.A. \& Hamdani A. The Elusive Quest for Global Governance Standards, 157(5) University of Pennsylvania Law Review 1263 (2009).

Bebchuk L.A. \& Roe M.J. A Theory of Path Dependence in Corporate Ownership and Governance, 52(1) Stanford Law Review 127 (1999). https://doi.org/10.2307/ 1229459

\footnotetext{
152 Varottil 2009.

153 Lucian A. Bebchuk \& Assaf Hamdani, The Elusive Quest for Global Governance Standards, 157(5) University of Pennsylvania Law Review 1263 (2009).
} 
Berkman H. et al. Political Connections and Minority Shareholder Protection: Evidence from Securities Market Regulation in China, 45(6) Journal of Financial and Quantitative Analysis 1391 (2010). https://doi.org/10.1017/s0022109010000608

Berle A.A. \& Means G.C. The Modern Corporation \& Private Property (New Brunswick, N.J.: Transaction Publishers, 1991). https://doi.org/10.4324/9781315133188

Bertrand M. et al. Ferreting out Tunneling: An Application to Indian Business Groups, 117(1) Quarterly Journal of Economics 121 (2002). https://doi.org/10.1162/003355302 753399463

Charreaux G. \& Desbrieres P. Corporate Governance: Stakeholder Value Versus Shareholder Value, 5(2) Journal of Management \& Governance 107 (2001). https:// doi.org/10.2139/ssrn.262902

Farrar J.H. Developing Corporate Governance in Greater China, 25(2) University of New South Wales Law Journal 462 (2002).

Feinerman J.V. New Hope for Corporate Governance in China?, The China Quarterly 590 (2007). https://doi.org/10.1017/s0305741007001592

Hansmann H. \& Kraakman R. Agency Problems and Legal Strategies in The Anatomy of Corporate Law: A Comparative and Functional Approach 21 (R. Kraakman et al. (eds.), Oxford: Oxford University Press, 2004).

Howson N.C. China's Company Law: One Step Forward, Two Steps Back? A Modest Complaint, 11(1) Columbia Journal of Asian Law 127 (1997).

Huang H. Shareholder Derivative Litigation in China: Empirical Findings and Comparative Analysis, 27 Banking and Finance Law Review 619 (2012).

Jensen M.C. \& Meckling W.H. Theory of the Firm: Managerial Behavior, Agency Costs and Ownership Structure, 3(4) Journal of Financial Economics 305 (1976). https://doi. org/10.1016/0304-405x(76)90026-x

Kirby W.C. China Unincorporated: Company Law and Business Enterprise in TwentiethCentury China, 54(1) Journal of Asian Studies 46 (1995). https://doi.org/10.2307/2058950

Lu T. et al. How Good Is Corporate Governance in China?, 17(1) China \& World Economy 83 (2007). https://doi.org/10.1111/j.1749-124x.2009.01132.x

Mitu Gulati G. et al. Connected Contracts, 47 UCLA Law Review 887 (2000). https:// doi.org/10.2139/ssrn.217590

Ong K.T.W. \& Baxter C.R. A Comparative Study of the Fundamental Elements of Chinese and English Company Law, 48(1) International \& Comparative Law Quarterly 88 (1999). https://doi.org/10.1017/s0020589300062898

Pant M. \& Pattanayak M. Insider Ownership and Firm Value: Evidence from Indian Corporate Sector, 42(16) Economic \& Political Weekly 1459 (2007).

Sarkar J. \& Sarkar S. Large Shareholder Activism in Corporate Governance in Developing Countries: Evidence from India, 1(3) International Review of Finance 161 (2000). https://doi.org/10.1111/1468-2443.00010

Schipani C.A. \& Liu J. Corporate Governance in China: Then and Now, Columbia Business Law Review 1 (2002). https://doi.org/10.2139/ssrn.315050 
Seddighi H.R. \& Nian W. The Chinese Stock Exchange Market: Operations and Efficiency, 14(11) Applied Financial Economics 785 (2004). https://doi.org/10.1080/ 0960310042000180826

Shleifer A. \& Vishny R.W. A Survey of Corporate Governance, 52(2) Journal of Finance 737 (1997). https://doi.org/10.1111/j.1540-6261.1997.tb04820.x

Srinivasan T.M. China and India: Economic Performance, Competition and Cooperation:An Update, 15(4) Journal of Asian Economics 613 (2004). https://doi.org/10.1016/ j.asieco.2004.05.011

Sun Q. et al. How Does Government Ownership Affect Firm Performance? Evidence from China's Privatization Experience, 29(1-2) Journal of Business Finance \& Accounting 1 (2002). https://doi.org/10.1111/1468-5957.00422

Varottil U. A Cautionary Tale of the Transplant Effect on Indian Corporate Governance, 21(1) National Law School of India Review 1 (2009).

Wang J. A Comparison of Shareholder Identity and Governance Mechanisms in the Monitoring of CEOs of Listed Companies in China, 21 (1) China Economic Review 24 (2010). https://doi.org/10.1016/j.chieco.2009.08.006

\section{Information about the author}

Arjya Majumdar (New Delhi, India) - Associate Professor, Jindal Global Law School, Director, Office of Academic Planning, Coordination and Interdisciplinarity, O.P. Jindal Global University (Sonipat, Narela Road, Haryana - 131001, NCR of Delhi, India; e-mail: abmajumdar@jgu.edu.in). 